\title{
A Potential of microRNAs for High-Content Screening
}

\author{
Andrius Serva, Christoph Claas, and Vytaute Starkuviene \\ BioQuant, University of Heidelberg, 69120 Heidelberg, Germany \\ Correspondence should be addressed to Vytaute Starkuviene, vytaute.starkuviene@bioquant.uni-heidelberg.de
}

Received 17 October 2010; Revised 15 May 2011; Accepted 3 June 2011

Academic Editor: Dmitry A. Stetsenko

Copyright ( 12011 Andrius Serva et al. This is an open access article distributed under the Creative Commons Attribution License, which permits unrestricted use, distribution, and reproduction in any medium, provided the original work is properly cited.

\begin{abstract}
In the last years miRNAs have increasingly been recognised as potent posttranscriptional regulators of gene expression. Possibly, miRNAs exert their action on virtually any biological process by simultaneous regulation of numerous genes. The importance of miRNA-based regulation in health and disease has inspired research to investigate diverse aspects of miRNA origin, biogenesis, and function. Despite the recent rapid accumulation of experimental data, and the emergence of functional models, the complexity of miRNA-based regulation is still far from being well understood. In particular, we lack comprehensive knowledge as to which cellular processes are regulated by which miRNAs, and, furthermore, how temporal and spatial interactions of miRNAs to their targets occur. Results from large-scale functional analyses have immense potential to address these questions. In this review, we discuss the latest progress in application of high-content and high-throughput functional analysis for the systematic elucidation of the biological roles of miRNAs.
\end{abstract}

\section{Introduction}

miRNAs (microRNAs) are $17-n t$ to $24-n t$ long noncoding RNAs that regulate gene expression in metazoans. miRNAs act by partially or completely complementary binding to their target mRNAs, resulting in translational repression and/or mRNA degradation [1,2]. miRNAs are predicted to affect the expression of nearly $60 \%$ of protein-coding mammalian genes $[3,4]$ and, thereby, to control many, if not all, biological processes. Fundamental changes at the cellular and organismal level, including development [5], aging [6], the stress response [7], cell proliferation [8, 9], and apoptosis $[10,11]$, were shown to be regulated by miRNAs. Furthermore, miRNAs have been implicated in various diseases, such as diabetes [12-14], cancer $[15,16]$, hepatitis C [17], neurodevelopmental (reviewed in [18]), and mental [19] disorders. Rapidly growing knowledge of miRNAs as potent regulators in health and disease makes miRNAs attractive as targets for therapeutic intervention $[20,21]$ as well as for diagnostic markers $[22,23]$.

Numerous previous publications have addressed miRNA biogenesis and action (for detailed reviews see [24, 25]). Briefly, miRNAs are transcribed as long primary transcripts (pri-miRNAs), most of which are polyadenylated and capped. Pri-miRNAs are initially cleaved in nucleus by a multiprotein complex, called Microprocessor, yielding 70-nt long stem-loop structured precursor miRNAs (premiRNAs). The key components of the Microprocessor complex are the RNase III enzyme Drosha and the doublestranded RNA-binding protein DGCR8/Pasha [26]. The excised pre-miRNA hairpin is then exported to the cytoplasm by Exportin-5 complexed with Ran-GTPase [27]. In the cytoplasm, the pre-miRNA is further processed to a 2022-nt long miRNA/miRNA* duplex by a second RNase III enzyme, Dicer, which is in a complex with the TRBP and PACT proteins $[28,29]$. Subsequently, the miRNA duplex is unwound by multiple helicases, which may be miRNAspecific and may regulate miRNA activity [30, 31]. The mRNA-targeting miRNA strand (guide strand) is loaded into the miRNA-induced silencing complex (miRISC). Until recently, it was assumed that the complementary miRNA* strand (passenger strand) is degraded, but there is now evidence that a substantial cohort of miRNA* species is functionally active [32]. The core components of miRISC are proteins of the Argonaute (AGO) [33] and GW182 protein families [34]. Individual miRNAs might need specific maturation steps [35-37].

Once incorporated into miRISC, the miRNA brings the complex to its target mRNAs by interacting with complementary binding sites, which can be present in multiple 
copies [38-40]. Each miRNA can usually affect more than one transcript and, as a consequence, many proteins simultaneously $[41,42]$. On the other hand, multiple miRNAs can repress expression of a single target mRNA [43-46]. miRNAs are postulated to preferentially bind to the $3^{\prime}$ untranslated regions ( $3^{\prime}$ UTRs) of transcripts [47]. However, recent experimental evidences prove the existence of a new class of miRNA targets containing miRNA binding sites in both their 5'UTR and $3^{\prime}$ UTR [48] or within the coding region of mRNA [49].

The complexity of miRNA-mediated modulation of gene expression is only beginning to be appreciated, and much research needs to be done in order to understand miRNA global and adaptive regulatory functions. In this review, we summarize available methodologies for modulating expression levels of endogenous miRNAs, as well as on the application of these strategies for high-content and highthroughput functional studies.

\section{RNA Silencing}

The discovery that small ncRNAs (noncoding RNAs) play pivotal roles in fundamental biological processes has considerably widened our knowledge of mechanisms of gene regulation in the last years $[50,51]$. siRNAs (small interfering RNAs) and miRNAs are the two best characterized classes of ncRNAs. Both are derived from dsRNA (double-stranded RNA) precursors and exert their inhibitory function on gene expression by Watson-Crick base-pairing to complementary sequences in target RNA molecules: an effect commonly referred to as gene silencing [2]. Moreover, both siRNAs and miRNAs share some components of the cellular effector machinery involved in gene silencing [52]. Usually, miRNAs modify expression of endogenous genes whereas siRNAs have evolved to defend genome integrity against foreign invaders, like viruses or transposons [53]. In mammals siRNAs are 21-22 nt long fragments often, but not always, derived from foreign dsRNA by Dicer [52, 54]. siRNAs are incorporated into the siRNA-induced silencing complex (siRISC) [55] and bind to perfectly matched sequences in target molecules. Typically, this induces degradation of the bound RNA, a function called RNAi (RNA interference) [53], and this property was widely implicated in functional studies over the last decade (see what follows).

Binding of miRNA to perfectly matched sequences in mRNA can also result in degradation of the mRNA [56], but usually, miRNAs bind to sites in mRNAs with only partial sequence complementarity. This results primarily in translational repression rather than degradation [57] but can also cause secondary nucleolytic degradation of the mRNA [24]. Conversely, binding of siRNAs to partly unmatched sequences in mRNAs can result in translational blockadepotentially interfering with the results from siRNA-based screening experiments [56].

\section{3. siRNA/shRNA-Based Screens}

In the last years RNAi has developed into a powerful tool for systematic studies of fundamental physiological and pathological processes. A number of large-scale screens have been completed, analysing diverse cellular processes. Recent impressive examples of genome-wide RNAi-based screens in human cells are provided by the work of Collinet et al. [58], who performed a high-content survey of genes involved in endocytosis, and by the study of Neumann et al., who used time-lapse microscopy in living cells to identify genes that play a role in cell division [59].

siRNA-based screens have also been performed in several model organisms. C. elegans and Drosophila are especially receptive to this type of genetic screening [60]. In C. elegans, for example, gene silencing can be accomplished by feeding bacteria that express long dsRNA (about 200-2000-bp-long) or by providing such dsRNA in the medium [61, 62]. RNAi in cultured cells of Drosophila can similarly be induced by adding in vitro transcribed dsRNA to the culture medium [63]. In mammalian cells, in contrast, short RNA duplexes of 21-29 bp have to be administered, because long dsRNA evokes a response of the innate immune system, which ultimately leads to apoptosis [64]. The short siRNAs can be chemically synthesized or derived from transcribed PCR products by digestion with recombinant Dicer or bacterial RNase III (esiRNAs-endoribonuclease-prepared short interfering RNAs) [64, 65]. siRNA-mediated knock-down can attain close to $100 \%$ reduction in the target mRNA. However, the effectiveness of an individual siRNA is hard to predict and, therefore, several siRNAs targeting different regions of the target mRNA have to be tested. Some authors suggest checking 4-6 siRNAs per gene to obtain reliable results in a screening experiment [66].

If stable knock-down is needed or if cells are difficult to transfect, short hairpin RNAs (shRNAs) can be used. The sequences encoding the shRNA can be cloned into plasmids or virus-derived vectors (lenti-, retro-, or adenoviral origin) [67-69]. In the case of "second generation" shRNAs, so called shRNA-miRs, the RNAi-triggering small RNA sequence is cloned into the backbone of a pri-miRNA [70]. This design principle, together with improved selection of the small RNA targeting sequence, improves both the production levels of small RNAs and the silencing efficiency. shRNA-miRs can be cloned into constructs carrying different promoters and used for tissue-specific or inducible expression [70].

\section{Modulation of miRNA Function as an Approach for Functional Screening}

Clearly, their biological importance per se makes analyses of miRNA expression and identification of their target mRNAs a focus of the current research. Yet specific features of miRNAs give them strong potential as tools in functional genomics. Firstly, miRNAs are able to change the translation of hundreds of mRNAs simultaneously and, by doing so, add another layer of regulation to gene expression [71]. In fact, miRNAs can influence the whole biological programs, including development, apoptosis, proliferation, and differentiation, not only through direct interactions with target mRNAs but also indirectly by altering expression of, for example, components of the translation or RNAi machinery [42]. 
In general, miRNAs effect only subtle modulation of target gene expression. Their pronounced effect on cellular behaviour might, therefore, be a consequence of their ability to influence multiple genes involved in a single pathway. Indeed, miRNA-based screens can provide lists enriched in functionally related targets: for example, a recent RNAi screen identified three target genes that phenocopy miR19 and cooperate in the regulation of phosphatidylinositol3 kinase-mediated survival signalling [72]. miRNA-based screens and, especially, a combination of miRNA- and siRNA-based screens, though laborious, might have a clear advantage over siRNA-based screens alone, since with siRNAs, downregulation of only single individual mRNAs is expected. On the other hand, enrichment of target genes with specific functions is not always found using current bioinformatic prediction tools [73]; therefore, the potential to organise hits of miRNA-based screens directly into functional networks is as yet unproven. The fact that a single mRNA can be inhibited by different miRNAs [74] also means that cellular phenotypes result from synergistic effects, complicating interpretation. Having an infrastructure for large-scale experimentation, complex and previously unanticipated regulatory patterns might be identified.

In contrast to the vast number of mRNAs that have to be knocked-down in comprehensive functional genomic approaches using siRNAs/shRNAs, the number of miRNAs that have to be analysed in a genome-wide screen is relatively low. To date, 1424 miRNAs have been identified in the human genome (miRBase database, release 17; http://www.mirbase.org/). Various in silico methods, developed to predict targets of miRNAs, estimate that between $10 \%$ and $60 \%$ of all mRNAs might be influenced by miRNAs $[3,4,75,76]$. Hence, the analysis of the comparatively small number of miRNAs could, in principle, cover the function of substantial fraction of human genes. To modulate the expression of the same number of genes by siRNA/shRNA would require about 44,000 to 66,000 different siRNA/shRNAs, taking into account the need for multiple reagents targeting the same mRNA (see above).

\section{Tools to Modulate miRNA Function}

Here, we will briefly describe approaches that are currently in use to modulate miRNA function and discuss their potential and limitations (Table 1). Basically, it is possible either to interfere with miRNA expression (loss-of-function assays) or to induce ectopic (over-) expression of miRNA (gain-offunction).

One possibility for analysis of miRNA would be a complete knock-out. This very precise intervention will result in a complete loss of function. The resulting phenotypes are, therefore, often stronger than those seen after knockdown. For some time, generation of knock-out phenotypes was feasible in mammals only by exploiting homologous recombination technology in mice [77]. More recently, germline competent embryonic stem cells have also been established in rat, so that homologous recombination can now be performed in this species as well [78]. The development of genome editing approaches, using engineered zinc finger nucleases, opened up the possibility to extend such analyses to other organisms and tissue culture cells [79]. Still, a gene knock-out is laborious and, if the work is given to a contractor, expensive. Many miRNAs are located in introns of protein coding genes; so knock-out of a miRNA can result in simultaneous inactivation of the "host" protein coding gene with potentially detrimental effects that are unrelated to miRNA action. Finally, as discussed below, it is often desirable to downregulate the function of several miRNAs together, which is not feasible through knock-out. Interference with multiple miRNAs that are not synthesized from a single polycistronic gene is much easier to achieve using a knock-down approach.

The knock-down of miRNAs can be performed by application of antisense oligonucleotides (ASOs). Usually, ASOs exert their effects independently of the cellular silencing machinery: their potential in biological assays was described as early as 1978 [80]. Since then, lot of experience has been gained in the design of stable, specific, and potent antisense reagents for research and therapeutic use. Since unmodified oligonucleotides are quickly degraded by nucleases when administered to cells, chemical modification is necessary to enhance stability and potency. (For a review on chemical modification used in antisense approaches, see [81].) Inactivation of complementary RNA can be achieved, for example, by delivery of DNA oligonucleotides. RNA/DNA hybrids are then recognized and cleaved by RNase $\mathrm{H}$ [82]. Alternatively, oligonucleotides can be coupled to ribozymes or DNAzymes that inactivate bound RNA by cleavage [81]. For the inactivation of miRNAs, RNA-based oligonucleotides that do not carry enzymatic activity have gained popularity. It is not clear whether these oligonucleotides work by inducing degradation of the targeted miRNA [83] or by forming stable ASO/miRNA heteroduplexes and, thereby, blocking miRNA function $[84,85]$.

ASOs and ribozymes that interfere with miRNA function are commonly referred to as antagomiRs and antagomiRzymes, respectively, and can be obtained from commercial sources. In addition, plasmid- and virus-derived vectors exist that both allow for simultaneous and permanent expression of antogomiRs targeting different miRNAs and permit measurement of expression levels by coexpression of a fluorescent reporter protein [86].

In principle, miRNA function can be inhibited at different stages [87]. For example, ASOs have been used to interfere with the maturation of pri-miRNA [88]. Targeted degradation of pri-miRNAs in the nucleus with RNase $\mathrm{H}$ based ASOs has also been tried [87]. Strategies to target primiRNAs could have the advantage of combined inhibition of several miRNAs transcribed from the same polycistronic gene locus. Experiments with siRNAs targeting the loop region of pre-miRNA have been reported [89], but the approach has not acquired much popularity: the loop region might be difficult to access, leading to inefficient knockdown of miRNA [87].

With regard to knock-down of protein-coding mRNAs, siRNA are nowadays in much wider use than ASOs, probably because siRNAs provide a more potent and efficient mode 


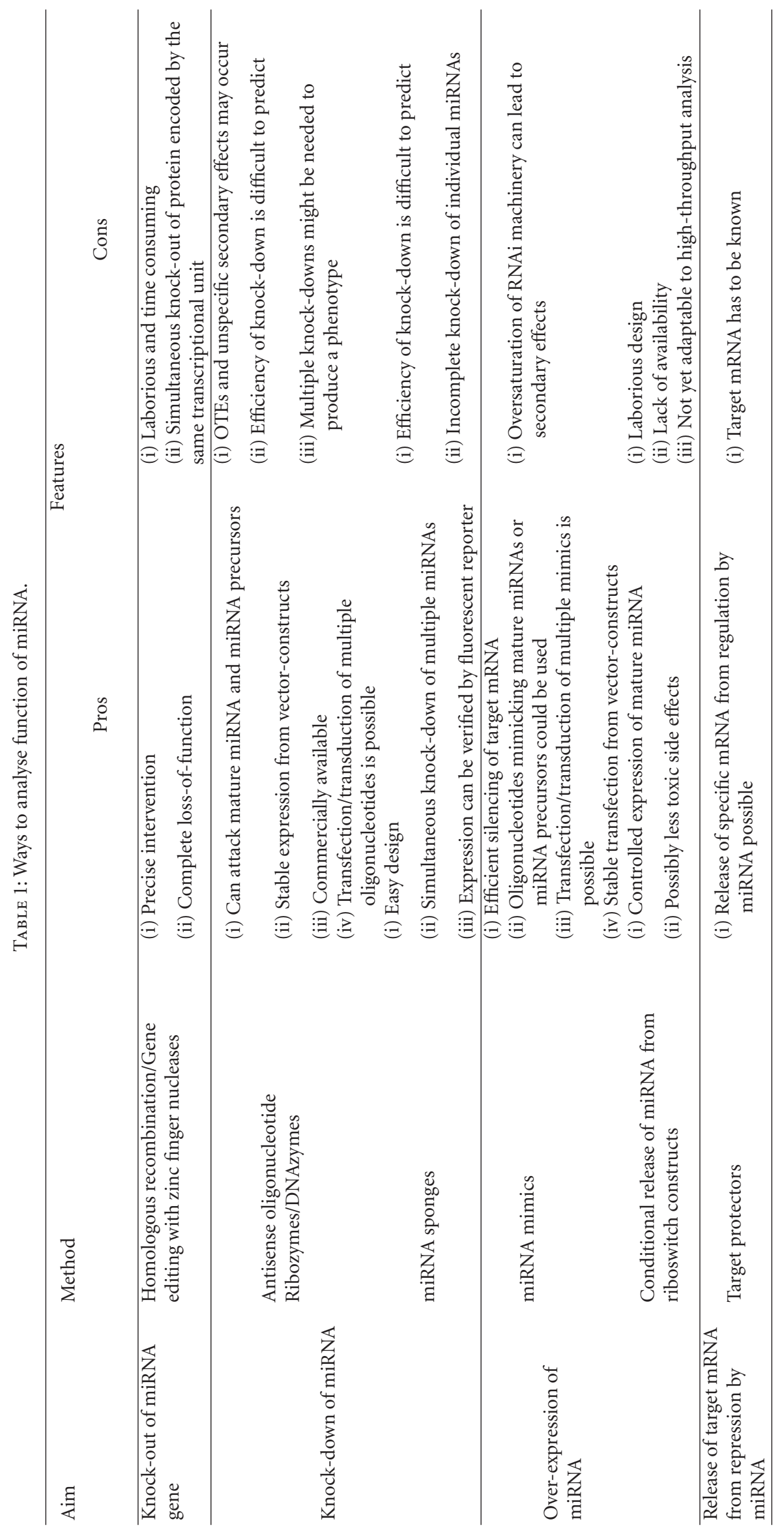


of intervention. In some model organisms, like zebrafish, however, a certain class of ASOs, called "morpholinos", is still indispensable for knock-down of gene expression and so far could not be replaced by siRNA-based approaches [90].

More recently, vector constructs have been devised that contain multiple binding sites for miRNAs, in order to compete with endogenous mRNAs for miRNA binding. Such miRNA sponges appeared to be a versatile tool for miRNA research [91]. Loya and colleagues analysed phenotypes when miR-7, miR-8, and miR-9a in Drosophila were downregulated by miRNA sponges. The authors found that miRNA sponges evoked the same phenotype as produced by homologous recombination, but in a milder form. This is expected: miRNA sponges do not completely sequester target miRNAs, because of the competitive binding of miRNAs to mRNAs. Still, this approach enables not only simultaneous down-regulation of several miRNAs but also inducible expression of miRNA sponges in specific tissues and at different time points, allowing spatiotemporal analysis of miRNA function. For instance, it was possible to assign the known role of miR-8 in neuromuscular junction formation by expression of miRNA sponge that targeted miR- 8 in muscle cells [92].

As an alternative to, or to complement, loss-of-function studies, miRNA-mimics can be used to achieve de novo or enhanced expression of miRNA (gain-of-function). miRNAmimics can be administered as synthetic small dsRNA with sequences identical to those of endogenous miRNAs $[93,94]$. They resemble siRNA molecules and are readily incorporated into the cellular RNA silencing machinery. If stable ectopic expression of miRNA is desired, constructs are at hand that allow expression of single or multiple miRNAs, and measurements of miRNA expression level by cotranscription of fluorescent reporter protein are possible (e.g., [95]). As for other vector-based constructs, the choice of suitable promotors can render tissue- and/or time-specific expression of miRNA-mimics possible. Importantly, molecules mimicking different maturation stages of endogenous miRNAs can be overexpressed and analysed.

Spatial and temporal regulation of miRNA expression can also be attained by allosteric ribozymes, riboswitches [96]. These are modular constructs containing an aptamer domain (an RNA sequence that specifically binds a chemical compound) embedded within a ribozyme and fused to a pri-miRNA analogue. This construct is functionally inactive in the absence of the appropriate chemical trigger. Upon application of the trigger substance (e.g., theophylline in the case of the cited work) a conformational change is induced in the ribozyme leading to its activation. The ribozyme will then cleave the modular RNA in cis, with pri-miRNA released from the construct and processed [96]. The large number of known aptamers and their endogenous and exogenous chemical triggers could develop this approach of conditional $R N A$ interference into a versatile alternative for inducible vector constructs, especially if toxic side effects in knockdown or knock-out approaches are of concern [97].

Finally, specific mRNAs can be released from miRNAmediated inhibition by application of target protectors. In experiments performed by Choi et al. in zebrafish [98], morpholino-based ASOs were used, which prevented miR430 binding by blocking seed-matched sites and neighbouring nucleotides in two target mRNAs. In this way, the authors succeeded in specifically interfering with miR-430-mediated translational repression. To conduct this type of experiment, it is necessary to know the targets of the miRNA of interest, but target protectors can be valuable in target validation and in characterization of miRNA: mRNA interactions.

\section{6. miRNA-Based Functional Screens}

The established infrastructure for siRNA/shRNA screens (i.e., robotics for large-scale sample preparation, automated data acquisition and analysis, data storage capacities) can easily be applied for high-throughput studies of miRNA function. As for siRNA-based screens, lipid-based transfection is most commonly used to achieve a transient overexpression [99] or inhibition [100] of miRNAs in cell culture. A number of screens were completed under conditions of miRNA stable overexpression $[40,45,101,102]$, achieved by transduction with retroviral vectors encoding specific miRNA genes [40]. Alternatively, constitutive overexpression or down-regulation of non-coding RNAs can be obtained by adenoviral vector-based systems $[69,103]$. The advantages of the reverse transfection method, coupled with an automatic liquid handling system, have been also utilized in miRNA-based screens by several groups with a high success rate $[104,105]$.

The first miRNA was described in the early 1990s [50], but the initial accumulation of data concerning regulatory roles was rather slow [106-108]. This in turn delayed the availability of reagents to modulate the activity of endogenous miRNAs, and so the first functional miRNAbased screen [100] was completed a couple of years later than siRNA-based screens [109]. As a consequence, though, miRNA-based screens could benefit a lot from prior experience accumulated with siRNA-based screens.

\section{Biological Processes Analysed in miRNA-Based Screens}

A number of miRNA-based screens have been completed during the last 5 years (Table 2). Two major groups of biological processes have been investigated so far, namely, (i) cell viability, proliferation, and apoptosis and (ii) gene transcription and/or activity regulation.

Numerous miRNAs were shown to inhibit (let-7, miR34a, miR-143, miR-145, miR-221, miR-222) [117-121] or to stimulate (miR-21, miR-133) [122, 123] cell proliferation. Moreover, recent studies demonstrated that a well-studied cluster of miR-17-92 can act both as oncogenes [124127] and as tumour suppressors [9, 128], and these roles are probably cell type- and/or environment-dependent. Context-dependent activity was also reported for miR-24: down-regulation of miR-24 inhibited proliferation of A549 cells but increased growth of HeLa cells [100].

A considerable increase in the numbers of miRNAs that regulate cell proliferation and apoptosis was obtained 
TABLE 2: miRNA-based functional screens.

\begin{tabular}{|c|c|c|c|c|c|c|}
\hline Model system & $\begin{array}{l}\text { Number of } \\
\text { miRNAs } \\
\text { screened }\end{array}$ & Type of regulation & $\begin{array}{l}\text { Phenotype } \\
\text { measured }\end{array}$ & Assay & Year & Reference \\
\hline HeLa and A549 & 95 & $\begin{array}{l}\text { Loss-of-function by } \\
\text { miRNA inhibitors }\end{array}$ & $\begin{array}{l}\text { Cell } \\
\text { proliferation } \\
\text { and apoptosis }\end{array}$ & $\begin{array}{l}\text { Cell counting and } \\
\text { caspase- } 3 / 7 \text { activity assay }\end{array}$ & 2005 & {$[100]$} \\
\hline $\begin{array}{l}\text { Primary hTERT- } \\
\text { immortalized } \\
\text { BJ-EHT fibroblasts }\end{array}$ & $\sim 450$ & $\begin{array}{l}\text { Gain-of-function by } \\
\text { stable miRNA } \\
\text { expression }\end{array}$ & $\begin{array}{l}\text { Sustained } \\
\text { proliferation }\end{array}$ & miR-Array & 2006 & {$[40]$} \\
\hline HeLa & $\sim 450$ & $\begin{array}{l}\text { Gain-of-function by } \\
\text { stable miRNA } \\
\text { expression }\end{array}$ & $\begin{array}{l}\mathrm{p} 27^{\mathrm{Kip} 1} \\
\text { regulation }\end{array}$ & $\begin{array}{l}\text { GFP reporter assay and } \\
\text { miR-Array }\end{array}$ & 2007 & {$[45]$} \\
\hline MDA-MB-453 & 187 & $\begin{array}{l}\text { Gain-of-function by } \\
\text { miRNA precursors }\end{array}$ & $\begin{array}{l}\text { TRAIL-induced } \\
\text { caspase-3 } \\
\text { activation }\end{array}$ & Caspase- $3 / 7$ activity assay & 2007 & {$[104]$} \\
\hline $\begin{array}{l}\text { Drosophila clone } 8 \\
\text { cells }\end{array}$ & $\begin{array}{l}77 / 78 \\
\text { miRNA loci }\end{array}$ & $\begin{array}{l}\text { Gain-of-function by } \\
\text { plasmid-based } \\
\text { miRNA expression }\end{array}$ & $\begin{array}{l}\text { Wg signaling } \\
\text { pathway } \\
\text { regulation }\end{array}$ & Luciferase reporter assay & 2007 & {$[110]$} \\
\hline $\begin{array}{l}\text { Neuroblastoma cell } \\
\text { lines }\end{array}$ & 8 & $\begin{array}{l}\text { Gain- and } \\
\text { loss-of-function by } \\
\text { miRNA mimics and } \\
\text { inhibitors }\end{array}$ & Proliferation & $\begin{array}{l}\text { Change in electrical } \\
\text { impedance }\end{array}$ & 2008 & {$[111]$} \\
\hline MCF7 & $\sim 450$ & $\begin{array}{l}\text { Gain-of-function by } \\
\text { stable miRNA } \\
\text { expression }\end{array}$ & Cell migration & $\begin{array}{l}\text { Trans-well cell migration } \\
\text { assay }\end{array}$ & 2008 & {$[101]$} \\
\hline HeLa & 91 & $\begin{array}{l}\text { Gain-of-function by } \\
\text { miRNA mimics }\end{array}$ & $\begin{array}{l}\text { p53 gene } \\
\text { activity }\end{array}$ & Luciferase reporter assay & 2009 & {$[38]$} \\
\hline HeLa & $\sim 450$ & $\begin{array}{l}\text { Gain-of-function by } \\
\text { stable miRNA } \\
\text { expression }\end{array}$ & $\begin{array}{l}\text { Per gene family } \\
\text { regulation }\end{array}$ & $\begin{array}{l}\text { GFP reporter assay and } \\
\text { miR-Array }\end{array}$ & 2009 & {$[102]$} \\
\hline $\begin{array}{l}\text { Primary ovarian } \\
\text { granulosa cells }\end{array}$ & 80 & $\begin{array}{l}\text { Gain-of-function by } \\
\text { miRNA precursors }\end{array}$ & $\begin{array}{l}\text { Progesterone, } \\
\text { testosterone and } \\
\text { estradiol release }\end{array}$ & $\begin{array}{l}\text { Enzyme immunoassay } \\
\text { (EIA) }\end{array}$ & 2009 & {$[112]$} \\
\hline HEK 293 & 266 & $\begin{array}{l}\text { Gain-of-function by } \\
\text { miRNA mimics }\end{array}$ & $\begin{array}{l}\mathrm{p} 21 \mathrm{Cip} / \mathrm{Waf} 1 \\
\text { regulation }\end{array}$ & Luciferase reporter assay & 2010 & {$[46]$} \\
\hline HCT-16 & 810 & $\begin{array}{l}\text { Gain-of-function by } \\
\text { miRNA mimics }\end{array}$ & $\begin{array}{l}\text { Cell viability in } \\
\text { the presence of } \\
\text { Bcl-2 family } \\
\text { inhibitor } \\
\text { ABT-263 }\end{array}$ & $\begin{array}{l}\text { CellTiter-Glo Luminescent } \\
\text { Cell Viability Assay }\end{array}$ & 2010 & {$[99]$} \\
\hline HEK 293T & 107 & $\begin{array}{l}\text { Gain-of-function by } \\
\text { miRNA mimics }\end{array}$ & $\begin{array}{l}\text { p53 gene } \\
\text { regulation }\end{array}$ & Luciferase reporter assay & 2010 & {$[39]$} \\
\hline $\begin{array}{l}\text { HCT } 116 \mathrm{p} 53^{+/+} \\
\text {H460 and MCF7 }\end{array}$ & 5 & $\begin{array}{l}\text { Gain-of-function by } \\
\text { miRNA precursors }\end{array}$ & $\begin{array}{l}\text { p53 gene } \\
\text { regulation }\end{array}$ & Western blot & 2010 & {$[10]$} \\
\hline Huh-7 & 327 & $\begin{array}{l}\text { Gain-of-function by } \\
\text { miRNA precursors }\end{array}$ & $\begin{array}{l}\text { Lipid droplet } \\
\text { formation and } \\
\text { growth }\end{array}$ & $\begin{array}{l}\text { Immunocytochemistry and } \\
\text { fluorescence microscopy }\end{array}$ & 2010 & {$[105]$} \\
\hline $\begin{array}{l}\text { Primary ovarian } \\
\text { granulosa cells }\end{array}$ & 80 & $\begin{array}{l}\text { Gain-of-function by } \\
\text { miRNA precursors }\end{array}$ & $\begin{array}{l}\text { Proliferation } \\
\text { and apoptosis }\end{array}$ & $\begin{array}{l}\text { Immunocytochemistry and } \\
\text { fluorescence microscopy }\end{array}$ & 2010 & {$[113]$} \\
\hline DLD-1 & 319 & $\begin{array}{l}\text { Gain-of-function by } \\
\text { miRNA precursors }\end{array}$ & Cell viability & $\begin{array}{l}\text { CellTiter-Glo Luminescent } \\
\text { Cell Viability Assay }\end{array}$ & 2010 & {$[11]$} \\
\hline HMEC & 328 & $\begin{array}{l}\text { Gain-of-function by } \\
\text { miRNA precursors }\end{array}$ & Proliferation & Fluorescence microscopy & 2010 & {$[114]$} \\
\hline
\end{tabular}


TABle 2: Continued.

\begin{tabular}{lllllll}
\hline Model system & $\begin{array}{l}\text { Number of } \\
\text { miRNAs } \\
\text { screened }\end{array}$ & Type of regulation & $\begin{array}{l}\text { Phenotype } \\
\text { measured }\end{array}$ & Assay & Reference \\
\hline MIA PaCa-2 & 445 & $\begin{array}{l}\text { Gain-of-function by } \\
\text { stable miRNA } \\
\text { expression }\end{array}$ & Proliferation & Custom-made microarray & 2010 & {$[115]$} \\
\hline HeLa and HeLa P4 & 8 & $\begin{array}{l}\text { Gain- and } \\
\text { loss-of-function by } \\
\text { miRNA precursors } \\
\text { and inhibitors }\end{array}$ & $\begin{array}{l}\text { Cell } \\
\text { proliferation } \\
\text { and trafficking }\end{array}$ & Fluorescence microscopy & 2011 & {$[116]$} \\
\hline
\end{tabular}

$[40,99,105]$ since Cheng et al. reported the first large-scale screen to identify mammalian miRNAs involved in these processes [100]. In 2007, Ovcharenko et al. performed a screen with 187 synthetic oligonucleotides to capture the modulators of TRAIL-induced apoptotic pathway [104]. They found that 34 of tested miRNAs modulate the activity of caspase-3. Recently, a gain-of-function miRNA-based screen was completed in human colorectal cancer DLD1 cells [11]. By measuring cell viability, authors not only confirmed function of already known oncogenic miR372 and miR-373 [40] but also discovered novel miRNAs involved in cell proliferation and apoptosis. miR-491 was among the strongest antiproliferative miRNAs, and further experimental analysis revealed that it induces apoptosis via direct down-regulation of antiapoptotic Bcl-xL [129]. miRNAs regulating expression of another member of Bcl-2 protein family, Mcl1, were identified by screening a library of 810 human miRNAs for the ability to confer resistance of cancer cells to ABT-263, an inhibitor of Bcl-2 family members [99]. Viability measurements of human colorectal cancer HCT-16 cells transiently transfected with miRNA mimics revealed 19 miRNAs that sensitized cells to ABT263. 15 of these miRNAs showed the same phenotype in melanoma CHL1 cells. Furthermore, 10 out of 12 strong sensitizer miRNAs that were analysed for targeting $3^{\prime}$ URT of Mcl1 were confirmed as direct regulators of the gene. These examples of the screens demonstrate that miRNAs that modulate sensitivity to chemotherapeutic agents can be identified and potentially, in future, used in cancer therapy $[21,130]$. The feasibility of such screens has vastly improved by the evolution of methods to quantify cell proliferation from straightforward cell counting [100] to recording of electrical impedance over 96 hours [111].

miRNAs acting on transcription and/or gene activity regulation are usually identified in so-called "target-based screening". In the most cases, luciferase or green fluorescent protein (GFP) is fused to the gene of interest and the strength of the detected signal is used to gauge the expression or activity of the test gene $[38,39,45,46,102]$. Using a functional genetic approach with stable expression of individual miRNAs [40], miR-221 and miR-222 were demonstrated to specifically regulate expression of tumour suppressor $\mathrm{p} 27^{\mathrm{Kip} 1}$ [45], miR-192/194 cluster-modulate expression of Per gene family [102].

The repertoire of cellular processes analysed by miRNA functional screens is expanding rapidly (Table 2). Doing
miRNA-based screens in appropriate cellular contexts, for instance, for miRNAs regulating steroidogenesis in ovarian cells [112], and for miRNAs regulating lipid droplet formation in hepatocytes [105] helps to ensure acquisition of physiologically relevant information.

\section{Gain-of-Function versus Loss-of-Function in miRNA-Based Screens}

Although reagents for gain-of-function and loss-of-function miRNA experiments are available to similar extents, nearly all reported screens to assess the function of miRNAs utilized the gain-of-function approach (Table 2). This trend probably arose because of the ease with which ectopic expression of miRNAs can be confirmed. For instance, exogenous reporter gene assays [116, 131], qRT-PCR, and Northern blotting and ribonuclease protection assay [40] are easily applicable methods to measure over-expression of miRNAs. In contrast, the only assays that have been extensively used so far to show the inhibition of endogenous miRNA activity have involved reporters $[38,100,128,132]$. The popularity of gain-of-function screens might additionally be explained by potentially easier evaluation. Over-expression of miRNAs might induce accentuated phenotypes, which might be not related to the levels of endogenous miRNAs, whereas the evaluation of data obtained under the conditions of miRNA down-regulation is possible only then one knows expression level of endogenous miRNAs in the test system. Acquisition of these data sets, therefore, needs thorough additional experimentation.

\section{Fluorescence Screening Microscopy for miRNA-Based Screens}

There are virtually no reasons why the read-out strategies in miRNA-based screens should be different from the ones established in siRNA-based screens. Nevertheless, we consider fluorescence microscopy screens to be highly advantageous. Features that make such microscopy ideal to analyse regulatory potential of miRNAs include the following: (i) rapid collection of large amount of data, (ii) feasibility of phenotype multiplexing, (iii) the possibility to acquire quantitative data on a cell-by-cell basis and/or population-based basis, and (iv) detection of subtle phenotypes $[133,134]$. One of the first studies applying this 
technology for functional miRNA studies was by Sirotkin and colleagues, who reported an immunocytochemistryand fluorescence-microscopy-based screen to identify miRNAs regulating proliferation and apoptosis [113]. Primary human ovarian cells were transfected with synthetic miRNA precursors, and PCNA and cyclin B1 proteins were used as markers of proliferation. The expression levels of Bax and caspase- 3 , in combination with the TUNEL assay, were used to determine the extent of apoptosis. The power of technology is demonstrated by another microscopybased screen: using automated image analysis and nucleus classification software, a novel antiproliferative activity of miR-320a was discovered [116]. The screen to identify miRNAs controlling lipid droplet formation in hepatocytes [105] illustrated the sensitivity of fluorescence microscopybased approach, which was comparable to the laborious biochemical assay-11 out of 327 transiently overexpressed human miRNAs were selected via an automated work flow as the most potent regulators of intracellular lipid content [105].

\section{Validation of Hits in miRNA-Based Screens}

In current screens, the list of primary hits involved in regulation of a biological pathway can be obtained reasonably fast, if necessary infrastructure is on place. The primary hit lists in siRNA/shRNA-based screens are usually validated by (i) repeating the assay with different types of reagents, and (ii) secondary assays, and (iii) rescue experiments, in which a phenotype caused by knock-down of a certain gene product is rescued by the over-expression of a construct that cannot be attacked by siRNA (either due to mutation or because of origin from another species). Currently, there is no clear agreement on criteria for successful validation of primary hit miRNAs, except from reproducing the phenotype with different reagents. Additionally, the effects caused by miRNA over-expression and down-regulation could be compared. Since this can be laborious, lists of miRNAs that cause a particular phenotype in screens may usefully be published without further analysis $[100,112,113]$, allowing follow-up by others.

In order to perform a follow-up research on hit miRNAs, prediction of their target genes needs to be done first. Many computational algorithms have been developed over the last decade to predict miRNA targets [135], and a combination of multiple algorithms is frequently used to narrow down the candidates. Interesting strategy was used in the studies of TRAIL-induced apoptosis when hits of miRNA-based screen were compared with those of siRNA-based screen in order to identify plausible interactions between miRNAs and their target mRNAs [104].

Many of the screens that have been completed so far have been extended to experimental identification and validation of the targets of the hit miRNAs (Table 3 ). The most widely used method to test a direct regulation of gene expression by miRNAs is based on reporter assays. The $3^{\prime}$ UTR, the $5^{\prime} \mathrm{UTR}$, or the whole gene is cloned immediately downstream of a reporter gene encoding luciferase or fluorescent protein. The construct is then transiently cotransfected with miRNA mimics or antimiRs into host cells and luciferase activity or fluorescence is measured after $24-48$ hours of incubation [ 10 , $11,38,99,110]$. Additional evidence that the target gene is directly regulated by an miRNA can be provided by mutating $[38,110]$ or deleting $[10,101]$ predicted miRNA binding sites in the $3^{\prime}$ UTR of a reporter vector. As controls, the entire $3^{\prime}$ UTR can be inserted in the reverse orientation [136] or truncated [110]. Frequently, qRT-PCR has been used to show degradation of target mRNAs in miRNA overexpressing cells $[10,45,46,101]$.

Since miRNAs can execute their regulatory action by repressing translation and/or promoting mRNA decay of target genes [137], measurement of the product protein level is an additional means to validate miRNA action $[11,45,46]$. Biochemical techniques for the isolation of target mRNAs were also shown to be rewarding [138-140]. Eventually, the action of miRNA can be tested by down-regulation of known or putative target genes and monitoring the resulting phenotypes [72, 105]. Observation of the same phenotype after both miRNA over-expression and down-regulation of its putative target genes strengthens evidence that the target identification was valid. Such tests might include downregulation of a single target as well as multiple ones. Complex evaluations are possible if combining several validation approaches. For example, changes in target protein level without any changes in a reporter assay would suggest that the miRNA does not directly target an affected gene but rather regulates its modulator or the whole pathway [99].

\section{Challenges of siRNA-, shRNAs-, and miRNA-Based Screens}

RNAi-based screens have turned to be extremely useful for studies in various fields of biology and medicine [59, 141143]. A robust assay, careful design of the experiment, reliable controls, and exhaustive testing of the reagents are crucial for successfully completing a screen, and several excellent reviews, describing the planning of RNAi screen experiments, have been published (e.g., $[60,144-146])$. We will now focus on some practical aspects of siRNA/shRNAbased screens that could be relevant while performing miRNA-based screens.

The analysis of siRNA-based screens is often complicated by off-target effects (OTEs): phenotypes caused by unspecific down-regulation of mRNAs. One source of OTEs is partial homology of siRNAs with unintended mRNAs. A different type of OTE arises from induction of cytokine production by siRNA/shRNA with certain sequence motifs [147], which ultimately results in apoptosis. Therefore, in the last years considerable effort has been invested in improving the performance of siRNAs/shRNAs. For example, induction of an interferon response can be mitigated by excluding GUrich sequence motifs in siRNA molecules [148]. Specificity can be considerably enhanced by altering the chemical backbone of siRNAs: examples are LNA (locked nucleic acid) nucleotide analogues or modifying ribosyl groups by addition of a $2^{\prime}$-O-methyl group at specific positions [149, 150]. 
TABLE 3: Validation assays in miRNA-based screens.

\begin{tabular}{|c|c|c|c|c|c|c|c|c|}
\hline \multirow{2}{*}{ Effector miRNA } & \multirow{2}{*}{ Target genes } & \multicolumn{5}{|c|}{ Validation assay } & \multirow{2}{*}{ Year } & \multirow{2}{*}{ Reference } \\
\hline & & Expression $^{\mathrm{a}}$ & Reporter $^{\mathrm{b}}$ & qRT-PCR & IS $^{\mathrm{c}}$ & $\operatorname{siRNA}^{\mathrm{d}}$ & & \\
\hline $\operatorname{miR}-372$ and -373 & LATS2 & + & + & + & + & & 2006 & {$[40]$} \\
\hline $\operatorname{miR}-221$ and -222 & $\mathrm{p} 27^{\mathrm{Kip} 1}$ & & + & & + & & 2007 & {$[45]$} \\
\hline miR-315 & Axin and Notum & & + & & & & 2007 & {$[110]$} \\
\hline $\operatorname{miR}-34^{\mathrm{a}}$ & $\mathrm{Bcl} 2$ and $\mathrm{MYCN}$ & & & & + & & 2008 & {$[111]$} \\
\hline miR-373 and $-520 c$ & $\mathrm{CD} 44$ & + & + & & & & 2008 & {$[101]$} \\
\hline $\operatorname{miR}-29^{\mathrm{a}, \mathrm{b}, \mathrm{c}}$ & p $85 \alpha$ and CDC42 & & + & & + & & 2009 & {$[38]$} \\
\hline miR-192 and -194 & Per1, 2 and 3 & & + & & & & 2009 & {$[102]$} \\
\hline 28 miRNAs & p21Cip/Waf1 & & + & & + & & 2010 & {$[46]$} \\
\hline 10 miRNAs & MCL1 & & + & & & & 2010 & [99] \\
\hline miR-1285 & p53 & & + & + & + & & 2010 & {$[39]$} \\
\hline miR-504 & p53 & & + & & + & & 2010 & {$[10]$} \\
\hline 11 miRNAs & Multiple genes & & & & & + & 2010 & {$[105]$} \\
\hline miR-491 & Bcl-xL & & + & + & + & & 2010 & {$[11]$} \\
\hline 28 miRNAs & p21Cip/Waf1 & & + & & + & & 2010 & {$[114]$} \\
\hline
\end{tabular}

Secondary or even toxic effects caused by transfection reagents alone and/or in combination with silencing RNA cannot be completely ruled out. Fortunately, current formulations contain 5 to 10 times less reagents than were required several years ago. Another approach is to pool several siRNAs against the same target, while using reduced amounts of each. The idea behind this approach is that the target mRNA will be attacked by all, or the majority of, siRNAs in the pool, and the specific down-regulations will act cumulatively, whereas OTEs of individual siRNAs will be too weak to affect results. The same concept of improved signal-to-noise ratio in observed phenotypes forms also the basis for the application of esiRNAs [65].

Despite these strategies, though, OTEs and unspecific secondary effects cannot be avoided completely. It is, therefore, essential to control for both. One option is to use several different siRNAs to target the same mRNA at independent sites. The probability that an observed phenotype corresponds to an on-target silencing effect rises with the number of siRNAs causing the same phenotype [151]. Moreover, it is of advantage to measure several cellular parameters (e.g., cell shape and size, number of cells) in a screen. Multiparametric analysis allows generation phenotypic profiles of individual siRNAs. A high degree of overlap in these profiles justifies strong confidence in the specificity of an observed phenotype $[58,151]$.

One of the most serious concerns in functional screens is possible oversaturation of the cellular silencing machinery by exogenous siRNA/shRNA and miRNA mimics. This can result in derepression of mRNAs that are regulated by endogenous miRNAs [152, 153]. Various strategies have been developed to deal with these problems (for a detailed compilation of strategies see [154]). Briefly, overloading the cellular RNA silencing machinery can be avoided by applying the lowest possible amounts of siRNA/shRNA to the cells. For instance, transcription from RNA Pol II-driven promotors, and use of inducible constructs, can be useful to control levels of vector-encoded shRNAs [70, 155]. Using vectors derived from adeno-associated virus can also be a way to induce a moderate level of stable shRNA expression in cells $[21,156]$. Coexpression of AGO-2 has also been described as an effective approach to overcome the problem of saturating the RNAi machinery by ectopic siRNA, shRNA, and miRNA [157]. Enhanced amounts of AGO-2 were shown to drive RNAi interference toward preferential knock-down of perfectly matched target mRNAs in diverse mammalian cell lines. Because, in addition, less siRNA/shRNA was needed for specific knock-down, and unspecific targeting of mRNAs was significantly reduced in the presence of ectopic AGO-2, the authors suggest that this strategy might result in reduced rates of false negatives and false positives in RNAi-based screening approaches. On the other hand, the suitability of the approach should be tested rigorously, as AGO-2 was recently shown to play a role in biogenesis of particular type of miRNAs [36, 37].

Finally, miRNA-based functional screens might suffer from neutral repression, when reduced transcript levels do not lead to measurable changes in cellular behaviour. Sometimes, residual protein is still sufficient to fulfil the required function; alternatively, feedback mechanisms exist that compensate functionally for the knock-down [158].

Usually, screens encompass thousands of genes or even the whole genomes; so it is hardly possible to look for functions that might be conferred by redundant gene function. Often, cellular functions are not controlled by just one protein, but by two or more isotypes or evolutionaryrelated forms of proteins to ensure higher reliability of the process, and metabolic pathways may be redundant. 
The need to use several siRNAs per protein, and multiple possible combinations of distinct siRNAs, limits studies that aim to identify redundant gene products to relatively small, directed screens. Conversely, highly homologous gene products, like, for example, splice variants, might have distinct cellular functions, but siRNAs might target all forms together (e.g., [159]). Similar concerns pertain to miRNA-based screens, as redundant activities of miRNAs in regulation of many biological processes is well documented [160]: Miska et al. reported that most miRNAs in C. elegans are individually dispensable [161], and Voorhoeve et al. found that miR-372 and miR-373 cooperate with oncogenic RAS in the development of testicular germ cell tumours [40]. A way to deal with miRNA redundancy could be the use of sensitized genetic backgrounds as described by Brenner et al. [162]. By deleting one of the two AGO genes in C. elegans the authors partially disabled the RNA silencing machinery. In addition, worms with defects in chromatin modification or transcriptional regulation were generated. Using these organisms allowed definition of biological roles for several individual miRNAs [162]. Additionally, synthetic phenotypes might be used to analyse functions of miRNAs [160].

The complexity of miRNA action presents a challenging task for high-throughput functional analysis. However, given our experience from RNAi screens over the last decade, with siRNAs and shRNAs in different model organisms, careful experimental design and exhaustive target validation makes this powerful technology indispensable for understanding the biological roles of miRNAs.

\section{Acknowledgments}

The authors are grateful to Professor Christine Clayton, $\mathrm{ZMBH}$, Heidelberg, for comments and careful reading of the manuscript. V. Starkuviene and C. Claas are supported by BMBF FORSYS ViroQuant (\#0313923), BMBF SysTec (0315523A), and Stiftung Baden Württemberg (PLS-Meth/11). A. Serva is supported by LGFG fellowship of Graduate Academy of Heidelberg University and HBIGS. A. Serva and C. Claas contributed equally to this work.

\section{References}

[1] A. S. Flynt and E. C. Lai, "Biological principles of microRNAmediated regulation: shared themes amid diversity," Nature Reviews Genetics, vol. 9, no. 11, pp. 831-842, 2008.

[2] R. W. Carthew and E. J. Sontheimer, "Origins and mechanisms of miRNAs and siRNAs," Cell, vol. 136, no. 4, pp. 642655, 2009.

[3] R. C. Friedman, K. K. Farh, C. B. Burge, and D. P. Bartel, "Most mammalian mRNAs are conserved targets of microRNAs," Genome Research, vol. 19, no. 1, pp. 92-105, 2009.

[4] B. P. Lewis, C. B. Burge, and D. P. Bartel, "Conserved seed pairing, often flanked by adenosines, indicates that thousands of human genes are microRNA targets," Cell, vol. 120, no. 1, pp. 15-20, 2005.

[5] J. Brennecke, D. R. Hipfner, A. Stark, R. B. Russell, and S. M. Cohen, "bantam encodes a developmentally regulated
microRNA that controls cell proliferation and regulates the proapoptotic gene hid in Drosophila," Cell, vol. 113, no. 1, pp. 25-36, 2003.

[6] M. Hackl, S. Brunner, K. Fortschegger et al., "miR-17, miR19b, miR-20a, and miR-106a are down-regulated in human aging," Aging Cell, vol. 9, no. 2, pp. 291-296, 2010.

[7] X. Huang, L. Ding, K. L. Bennewith et al., "Hypoxiainducible mir-210 regulates normoxic gene expression involved in tumor initiation," Molecular Cell, vol. 35, no. 6, pp. 856-867, 2009.

[8] C. D. Johnson, A. Esquela-Kerscher, G. Stefani et al., "The let7 microRNA represses cell proliferation pathways in human cells," Cancer Research, vol. 67, no. 16, pp. 7713-7722, 2007.

[9] Z. Yu, C. Wang, M. Wang et al., "A cyclin D1/microRNA $17 / 20$ regulatory feedback loop in control of breast cancer cell proliferation," Journal of Cell Biology, vol. 182, no. 3, pp. 509517, 2008.

[10] W. Hu, C. S. Chan, R. Wu et al., "Negative regulation of tumor suppressor p53 by microRNA miR-504," Molecular Cell, vol. 38, no. 5, pp. 689-699, 2010.

[11] H. Nakano, T. Miyazawa, K. Kinoshita, Y. Yamada, and T. Yoshida, "Functional screening identifies a microRNA, miR491 that induces apoptosis by targeting Bcl-X(L)in colorectal cancer cells," International Journal of Cancer, vol. 127, no. 5, pp. 1072-1080, 2010.

[12] A. K. Pandey, P. Agarwal, K. Kaur, and M. Datta, "MicroRNAs in diabetes: tiny players in big disease," Cellular Physiology and Biochemistry, vol. 23, no. 4-6, pp. 221-232, 2009.

[13] H. Y. Ling, H. S. Ou, S. D. Feng et al., "Changes in microrna (mir) profile and effects of mir-320 in insulin-resistant 3t311 adipocytes," Clinical and Experimental Pharmacology and Physiology, vol. 36, no. 9, pp. e32-e39, 2009.

[14] X. Tang, G. Tang, and S. Özcan, "Role of microRNAs in diabetes," Biochimica et Biophysica Acta, vol. 1779, no. 11, pp. 697-701, 2008.

[15] C. M. Croce, "Causes and consequences of microRNA dysregulation in cancer," Nature Reviews Genetics, vol. 10, no. 10, pp. 704-714, 2009.

[16] S. S. Myatt, J. Wang, L. J. Monteiro et al., "Definition of microRNAs that repress expression of the tumor suppressor gene FOXO1 in endometrial cancer," Cancer Research, vol. 70, no. 1, pp. 367-377, 2010.

[17] C. L. Jopling, M. Yi, A. M. Lancaster, S. M. Lemon, and P. Sarnow, "Molecular biology: modulation of hepatitis $\mathrm{C}$ virus RNA abundance by a liver-specific microRNA," Science, vol. 309, no. 5740, pp. 1577-1581, 2005.

[18] S. Chang, S. Wen, D. Chen, and P. Jin, "Small regulatory RNAs in neurodevelopmental disorders," Human Molecular Genetics, vol. 18, no. 1, pp. R18-R26, 2009.

[19] Y. Xu, F. Li, B. Zhang et al., "MicroRNAs and target site screening reveals a pre-microRNA-30e variant associated with schizophrenia," Schizophrenia Research, vol. 119, no. 13, pp. 219-227, 2010.

[20] F. Takeshita, L. Patrawala, M. Osaki et al., "Systemic delivery of synthetic microRNA-16 inhibits the growth of metastatic prostate tumors via downregulation of multiple cell-cycle genes," Molecular Therapy, vol. 18, no. 1, pp. 181-187, 2010.

[21] J. Kota, R. R. Chivukula, K. A. O’Donnell et al., “Therapeutic microRNA delivery suppresses tumorigenesis in a murine liver cancer model," Cell, vol. 137, no. 6, pp. 1005-1017, 2009.

[22] S. Volinia, G. A. Calin, C. G. Liu et al., "A microRNA expression signature of human solid tumors defines cancer gene targets," Proceedings of the National Academy of Sciences 
of the United States of America, vol. 103, no. 7, pp. 2257-2261, 2006.

[23] S. Toffanin, Y. Hoshida, A. Lachenmayer et al., "MicroRNAbased classification of hepatocellular carcinoma and oncogenic role of miR-517a," Gastroenterology, vol. 140, no. 5, pp. 1618-1628.e16, 2011.

[24] E. Huntzinger and E. Izaurralde, "Gene silencing by microRNAs: contributions of translational repression and mRNA decay," Nature Reviews Genetics, vol. 12, no. 2, pp. 99-110, 2011.

[25] J. Krol, I. Loedige, and W. Filipowicz, "The widespread regulation of microRNA biogenesis, function and decay," Nature Reviews Genetics, vol. 11, no. 9, pp. 597-610, 2010.

[26] A. M. Denli, B. B. Tops, R. H. Plasterk, R. F. Ketting, and G. J. Hannon, "Processing of primary microRNAs by the microprocessor complex,” Nature, vol. 432, no. 7014, pp. 231-235, 2004.

[27] R. Yi, Y. Qin, I. G. Macara, and B. R. Cullen, "Exportin5 mediates the nuclear export of pre-microRNAs and short hairpin RNAs," Genes and Development, vol. 17, no. 24, pp. 3011-3016, 2003.

[28] Y. Lee, I. Hur, S.-Y. Park, Y.-K. Kim, M. R. Suh, and V. N. Kim, "The role of PACT in the RNA silencing pathway," EMBO Journal, vol. 25, no. 3, pp. 522-532, 2006.

[29] T. P. Chendrimada, R. I. Gregory, E. Kumaraswamy et al., "TRBP recruits the Dicer complex to Ago2 for microRNA processing and gene silencing," Nature, vol. 436, no. 7051, pp. 740-744, 2005.

[30] D. W. Salzman, J. Shubert-Coleman, and H. Furneaux, "P68 RNA helicase unwinds the human let-7 microRNA precursor duplex and is required for let-7-directed silencing of gene expression," The Journal of Biological Chemistry, vol. 282, no. 45, pp. 32773-32779, 2007.

[31] G. B. Robb and T. M. Rana, "RNA helicase a interacts with RISC in human cells and functions in RISC loading," Molecular Cell, vol. 26, no. 4, pp. 523-537, 2007.

[32] J. S. Yang, M. D. Phillips, D. Betel et al., "Widespread regulatory activity of vertebrate microRNA* species," RNA, vol. 17, no. 2, pp. 312-326, 2011.

[33] G. Meister, M. Landthaler, A. Patkaniowska, Y. Dorsett, G. Teng, and T. Tuschl, "Human Argonaute2 mediates RNA cleavage targeted by miRNAs and siRNAs," Molecular Cell, vol. 15, no. 2, pp. 185-197, 2004.

[34] A. Eulalio, E. Huntzinger, and E. Izaurralde, "GW182 interaction with Argonaute is essential for miRNA-mediated translational repression and mRNA decay," Nature Structural and Molecular Biology, vol. 15, no. 4, pp. 346-353, 2008.

[35] J. Winter, S. Jung, S. Keller, R. I. Gregory, and S. Diederichs, "Many roads to maturity: microRNA biogenesis pathways and their regulation," Nature Cell Biology, vol. 11, no. 3, pp. 228-234, 2009.

[36] S. Cheloufi, C. O. Dos Santos, M. M. Chong, and G. J. Hannon, "A dicer-independent miRNA biogenesis pathway that requires Ago catalysis," Nature, vol. 465, no. 7298, pp. 584-589, 2010.

[37] D. Cifuentes, H. Xue, D. W. Taylor et al., "A novel miRNA processing pathway independent of dicer requires Argonaute2 catalytic activity," Science, vol. 328, no. 5986, pp. 1694-1698, 2010.

[38] S. Y. Park, J. H. Lee, M. Ha, J. W. Nam, and V. N. Kim, "miR29 miRNAs activate p53 by targeting p $85 \alpha$ and CDC42," Nature Structural and Molecular Biology, vol. 16, no. 1, pp. 23-29, 2009.
[39] S. Tian, S. Huang, S. Wu, W. Guo, J. Li, and X. He, "MicroRNA-1285 inhibits the expression of p53 by directly targeting its 3' untranslated region," Biochemical and Biophysical Research Communications, vol. 396, no. 2, pp. 435439, 2010.

[40] P. M. Voorhoeve, C. le Sage, M. Schrier et al., "A genetic screen implicates miRNA-372 and miRNA-373 as oncogenes in testicular germ cell tumors," Cell, vol. 124, no. 6, pp. 1169$1181,2006$.

[41] D. Baek, J. Villén, C. Shin, F. D. Camargo, S. P. Gygi, and D. P. Bartel, "The impact of microRNAs on protein output," Nature, vol. 455, no. 7209, pp. 64-71, 2008.

[42] M. Selbach, B. Schwanhäusser, N. Thierfelder, Z. Fang, R. Khanin, and N. Rajewsky, "Widespread changes in protein synthesis induced by microRNAs," Nature, vol. 455, no. 7209, pp. 58-63, 2008.

[43] N. Bushati and S. M. Cohen, "MicroRNA functions," Annual Review of Cell and Developmental Biology, vol. 23, pp. 175205, 2007.

[44] L. Du, J. J. Schageman, M. C. Subauste et al., "MiR-93, miR98, and miR-197 regulate expression of tumor suppressor gene FUS1," Molecular Cancer Research, vol. 7, no. 8, pp. 1234-1243, 2009.

[45] C. le Sage, R. Nagel, D. A. Egan et al., "Regulation of the $\mathrm{p} 27^{\text {Kip } 1}$ tumor suppressor by miR-221 and miR-222 promotes cancer cell proliferation," The EMBO Journal, vol. 26, no. 15, pp. 3699-3708, 2007.

[46] S. Wu, S. Huang, J. Ding et al., "Multiple microRNAs modulate p21Cip1/Waf1 expression by directly targeting its $3^{\prime}$ untranslated region," Oncogene, vol. 29, no. 15, pp. 23022308, 2010.

[47] R. S. Pillai, "MicroRNA function: multiple mechanisms for a tiny RNA?" RNA, vol. 11, no. 12, pp. 1753-1761, 2005.

[48] I. Lee, S. S. Ajay, J. I. Yook et al., "New class of microRNA targets containing simultaneous $5^{\prime}$-UTR and $3^{\prime}$-UTR interaction sites," Genome Research, vol. 19, no. 7, pp. 1175-1183, 2009.

[49] I. Elcheva, S. Goswami, F. K. Noubissi, and V. S. Spiegelman, "CRD-BP protects the coding region of $\beta \operatorname{TrCP} 1$ mRNA from miR-183-mediated degradation," Molecular Cell, vol. 35, no. 2, pp. 240-246, 2009.

[50] R. C. Lee, R. L. Feinbaum, and V. Ambros, "The C. elegans heterochronic gene lin- 4 encodes small RNAs with antisense complementarity to lin-14," Cell, vol. 75, no. 5, pp. 843-854, 1993.

[51] A. Fire, S. Xu, M. K. Montgomery, S. A. Kostas, S. E. Driver, and C. C. Mello, "Potent and specific genetic interference by double-stranded RNA in Caenorhabditis elegans," Nature, vol. 391, no. 6669, pp. 806-811, 1998.

[52] G. Meister and T. Tuschl, "Mechanisms of gene silencing by double-stranded RNA," Nature, vol. 431, no. 7006, pp. 343349, 2004.

[53] C. C. Mello and D. Conte Jr., "Revealing the world of RNA interference," Nature, vol. 431, no. 7006, pp. 338-342, 2004.

[54] Y. Tomari and P. D. Zamore, "Perspective: machines for RNAi," Genes and Development, vol. 19, no. 5, pp. 517-529, 2005.

[55] S. M. Hammond, E. Bernstein, D. Beach, and G. J. Hannon, "An RNA-directed nuclease mediates post-transcriptional gene silencing in cells," Nature, vol. 404, no. 6775, pp. 293296, 2000.

[56] Y. Zeng, R. Yi, and B. R. Cullen, "MicroRNAs and small interfering RNAs can inhibit mRNA expression by similar 
mechanisms," Proceedings of the National Academy of Sciences of the United States of America, vol. 100, no. 17, pp. 97799784, 2003.

[57] W. Filipowicz, S. N. Bhattacharyya, and N. Sonenberg, "Mechanisms of post-transcriptional regulation by microRNAs: are the answers in sight?" Nature Reviews Genetics, vol. 9, no. 2, pp. 102-114, 2008.

[58] C. Collinet, M. Stöter, C. R. Bradshaw et al., "Systems survey of endocytosis by multiparametric image analysis," Nature, vol. 464, no. 7286, pp. 243-249, 2010.

[59] B. Neumann, T. Walter, J. K. Hériché et al., "Phenotypic profiling of the human genome by time-lapse microscopy reveals cell division genes," Nature, vol. 464, no. 7289, pp. 721-727, 2010.

[60] M. Boutros and J. Ahringer, "The art and design of genetic screens: RNA interference," Nature Reviews Genetics, vol. 9, no. 7, pp. 554-566, 2008.

[61] L. Timmons, D. L. Court, and A. Fire, "Ingestion of bacterially expressed dsRNAs can produce specific and potent genetic interference in Caenorhabditis elegans," Gene, vol. 263, no. 1-2, pp. 103-112, 2001.

[62] L. Timmons and A. Fire, "Specific interference by ingested dsRNA," Nature, vol. 395, no. 6705, p. 854, 1998.

[63] J. C. Clemens, C. A. Worby, N. Simonson-Leff et al., "Use of double-stranded RNA interference in Drosophila cell lines to dissect signal transduction pathways," Proceedings of the National Academy of Sciences of the United States of America, vol. 97, no. 12, pp. 6499-6503, 2000.

[64] S. M. Elbashir, J. Harborth, W. Lendeckel, A. Yalcin, K. Weber, and T. Tuschl, "Duplexes of 21-nucleotide RNAs mediate RNA interference in cultured mammalian cells," Nature, vol. 411, no. 6836, pp. 494-498, 2001.

[65] R. Kittler, L. Pelletier, A. K. Heninger et al., "Genome-scale RNAi profiling of cell division in human tissue culture cells," Nature Cell Biology, vol. 9, no. 12, pp. 1401-1412, 2007.

[66] R. König, C. Y. Chiang, B. P. Tu et al., "A probability-based approach for the analysis of large-scale RNAi screens," Nature Methods, vol. 4, no. 10, pp. 847-849, 2007.

[67] P. J. Paddison, J. M. Silva, D. S. Conklin et al., "A resource for large-scale RNA-interference-based screens in mammals," Nature, vol. 428, no. 6981, pp. 427-431, 2004.

[68] K. Berns, E. M. Hijmans, J. Mullenders et al., "A large-scale RNAi screen in human cells identifies new components of the p53 pathway," Nature, vol. 428, no. 6981, pp. 431-437, 2004.

[69] J. Moffat, D. A. Grueneberg, X. Yang et al., "A lentiviral RNAi library for human and mouse genes applied to an arrayed viral high-content screen," Cell, vol. 124, no. 6, pp. 12831298, 2006.

[70] J. M. Silva, M. Z. Li, K. Chang et al., "Second-generation shRNA libraries covering the mouse and human genomes," Nature Genetics, vol. 37, no. 11, pp. 1281-1288, 2005.

[71] M. Garofalo and C. M. Croce, "MicroRNAs: master regulators as potential therapeutics in cancer," Annual Review of Pharmacology and Toxicology, vol. 51, pp. 25-43, 2011.

[72] K. J. Mavrakis, A. L. Wolfe, E. Oricchio et al., "Genome-wide RNA-mediated interference screen identifies miR-19 targets in notch-induced T-cell acute lymphoblastic leukaemia," Nature Cell Biology, vol. 12, no. 4, pp. 372-379, 2010.

[73] D. P. Bartel, "MicroRNAs: target recognition and regulatory functions," Cell, vol. 136, no. 2, pp. 215-233, 2009.

[74] A. Krek, D. Grün, M. N. Poy et al., "Combinatorial microRNA target predictions," Nature Genetics, vol. 37, no. 5, pp. 495-500, 2005.
[75] B. John, A. J. Enright, A. Aravin, T. Tuschl, C. Sander, and D. S. Marks, "Human microRNA targets," PLoS Biology, vol. 2, no. 11, article e363, 2004.

[76] X. Xie, J. Lu, E. J. Kulbokas et al., "Systematic discovery of regulatory motifs in human promoters and 3' UTRs by comparison of several mammals," Nature, vol. 434, no. 7031, pp. 338-345, 2005.

[77] M. R. Capecchi, "Generating mice with targeted mutations," Nature Medicine, vol. 7, no. 10, pp. 1086-1090, 2001.

[78] C. Tong, P. Li, N. L. Wu, Y. Yan, and Q. L. Ying, "Production of p53 gene knockout rats by homologous recombination in embryonic stem cells," Nature, vol. 467, no. 7312, pp. 211213, 2010.

[79] F. D. Urnov, E. J. Rebar, M. C. Holmes, H. S. Zhang, and P. D. Gregory, "Genome editing with engineered zinc finger nucleases," Nature Reviews Genetics, vol. 11, no. 9, pp. 636646, 2010.

[80] P. C. Zamecnik and M. L. Stephenson, "Inhibition of Rous sarcoma virus replication and cell transformation by a specific oligodeoxynucleotide," Proceedings of the National Academy of Sciences of the United States of America, vol. 75, no. 1, pp. 280-284, 1978.

[81] J. Kurreck, "Antisense technologies: improvement through novel chemical modifications," European Journal of Biochemistry, vol. 270, no. 8, pp. 1628-1644, 2003.

[82] T. A. Vickers, S. Koo, C. F. Bennett, S. T. Crooke, N. M. Dean, and B. F. Baker, "Efficient reduction of target RNAs by small interfering RNA and RNase $\mathrm{H}$-dependent antisense agents. A comparative analysis," The Journal of Biological Chemistry, vol. 278, no. 9, pp. 7108-7118, 2003.

[83] J. Krützfeldt, S. Kuwajima, R. Braich et al., "Specificity, duplex degradation and subcellular localization of antagomirs," Nucleic Acids Research, vol. 35, no. 9, pp. 28852892, 2007.

[84] J. Elmén, M. Lindow, A. Silahtaroglu et al., "Antagonism of microRNA-122 in mice by systemically administered LNAantimiR leads to up-regulation of a large set of predicted target mRNAs in the liver," Nucleic Acids Research, vol. 36, no. 4, pp. 1153-1162, 2008.

[85] S. Davis, S. Propp, S. M. Freier et al., "Potent inhibition of microRNA in vivo without degradation," Nucleic Acids Research, vol. 37, no. 1, pp. 70-77, 2009.

[86] Y. Lu, J. Xiao, H. Lin et al., "A single anti-microRNA antisense oligodeoxyribonucleotide (AMO) targeting multiple microRNAs offers an improved approach for microRNA interference," Nucleic Acids Research, vol. 37, no. 3, article e24, 2009.

[87] C. C. Esau, "Inhibition of microRNA with antisense oligonucleotides," Methods, vol. 44, no. 1, pp. 55-60, 2008.

[88] W. P. Kloosterman, A. K. Lagendijk, R. F. Ketting, J. D. Moulton, and R. H. Plasterk, "Targeted inhibition of miRNA maturation with morpholinos reveals a role for miR-375 in pancreatic islet development," PLoS Biology, vol. 5, no. 8, article e203, 2007.

[89] Y. S. Lee, H. K. Kim, S. Chung, K. S. Kim, and A. Dutta, "Depletion of human micro-RNA miR-125b reveals that it is critical for the proliferation of differentiated cells but not for the down-regulation of putative targets during differentiation," The Journal of Biological Chemistry, vol. 280, no. 17, pp. 16635-16641, 2005.

[90] J. S. Eisen and J. C. Smith, "Controlling morpholino experiments: don't stop making antisense," Development, vol. 135, no. 10, pp. 1735-1743, 2008. 
[91] M. S. Ebert, J. R. Neilson, and P. A. Sharp, "MicroRNA sponges: competitive inhibitors of small RNAs in mammalian cells," Nature Methods, vol. 4, no. 9, pp. 721-726, 2007.

[92] C. M. Loya, C. S. Lu, D. Van Vactor, and T. A. Fulga, "Transgenic microRNA inhibition with spatiotemporal specificity in intact organisms," Nature Methods, vol. 6, no. 12, pp. 897903, 2009.

[93] N. Tsuda, S. Ishiyama, Y. Li, C. G. Ioannides, J. L. Abbruzzese, and D. Z. Chang, "Synthetic microRNA designed to target glioma-associated antigen 1 transcription factor inhibits division and induces late apoptosis in pancreatic tumor cells," Clinical Cancer Research, vol. 12, no. 21, pp. 6557-6564, 2006.

[94] R. Garzon, C. E. Heaphy, V. Havelange et al., "MicroRNA 29b functions in acute myeloid leukemia," Blood, vol. 114, no. 26, pp. 5331-5341, 2009.

[95] K. H. Chung, C. C. Hart, S. Al-Bassam et al., "Polycistronic RNA polymerase II expression vectors for RNA interference based on BIC/miR-155," Nucleic Acids Research, vol. 34, no. 7, p. e53, 2006.

[96] D. Kumar, C. I. An, and Y. Yokobayashi, "Conditional RNA interference mediated by allosteric ribozyme," Journal of the American Chemical Society, vol. 131, no. 39, pp. 1390613907, 2009.

[97] M. Schmidt-Supprian and K. Rajewsky, "Vagaries of conditional gene targeting," Nature Immunology, vol. 8, no. 7, pp. 665-668, 2007.

[98] W. Y. Choi, A. J. Giraldez, and A. F. Schier, “Target protectors reveal dampening and balancing of nodal agonist and antagonist by miR-430," Science, vol. 318 , no. 5848, pp. 271$274,2007$.

[99] L. T. Lam, X. Lu, H. Zhang, R. R. Lesniewski, S. H. Rosenberg, and D. Semizarov, "A microRNA screen to identify modulators of sensitivity to BCL2 inhibitor ABT-263 (navitoclax)," Molecular Cancer Therapeutics, vol. 9, no. 11, pp. 2943-2950, 2010.

[100] A. M. Cheng, M. W. Byrom, J. Shelton, and L. P. Ford, "Antisense inhibition of human miRNAs and indications for an involvement of miRNA in cell growth and apoptosis," Nucleic Acids Research, vol. 33, no. 4, pp. 1290-1297, 2005.

[101] Q. Huang, K. Gumireddy, M. Schrier et al., "The microRNAs miR-373 and miR-520c promote tumour invasion and metastasis," Nature Cell Biology, vol. 10, no. 2, pp. 202-210, 2008.

[102] R. Nagel, L. Clijsters, and R. Agami, "The miRNA-192/194 cluster regulates the Period gene family and the circadian clock," FEBS Journal, vol. 276, no. 19, pp. 5447-5455, 2009.

[103] T. Subramanian and G. Chinnadurai, "Temperature-sensitive replication-competent adenovirus shRNA vectors to study cellular genes in virus-induced apoptosis," Methods in Molecular Medicine, vol. 130, pp. 125-134, 2007.

[104] D. Ovcharenko, K. Kelnar, C. Johnson, N. Leng, and D. Brown, "Genome-scale microRNA and small interfering RNA screens identify small RNA modulators of TRAILinduced apoptosis pathway," Cancer Research, vol. 67, no. 22, pp. 10782-10788, 2007.

[105] R. Whittaker, P. A. Loy, E. Sisman et al., "Identification of microRNAs that control lipid droplet formation and growth in hepatocytes via high-content screening," Journal of Biomolecular Screening, vol. 15, no. 7, pp. 798-805, 2010.

[106] B. Wightman, I. Ha, and G. Ruvkun, "Posttranscriptional regulation of the heterochronic gene lin-14 by lin- 4 mediates temporal pattern formation in C. elegans," Cell, vol. 75, no. 5, pp. 855-862, 1993.
[107] B. J. Reinhart, F. J. Slack, M. Basson et al., "The 21-nucleotide let-7 RNA regulates developmental timing in Caenorhabditis elegans," Nature, vol. 403, no. 6772, pp. 901-906, 2000.

[108] A. E. Pasquinelli, B. J. Reinhart, F. Slack et al., "Conservation of the sequence and temporal expression of let-7 heterochronic regulatory RNA," Nature, vol. 408, no. 6808, pp. 86-89, 2000.

[109] P. Aza-Blanc, C. L. Cooper, K. Wagner, S. Batalov, Q. L. Deveraux, and M. P. Cooke, "Identification of modulators of TRAIL-induced apoptosis via RNAi-based phenotypic screening," Molecular Cell, vol. 12, no. 3, pp. 627-637, 2003.

[110] S. J. Silver, J. W. Hagen, K. Okamura, N. Perrimon, and E. C. Lai, "Functional screening identifies miR-315 as a potent activator of Wingless signaling," Proceedings of the National Academy of Sciences of the United States of America, vol. 104, no. 46, pp. 18151-18156, 2007.

[111] K. A. Cole, E. F. Attiyeh, Y. P. Mosse et al., "A functional screen identifies miR-34a as a candidate neuroblastoma tumor suppressor gene," Molecular Cancer Research, vol. 6, no. 5, pp. 735-742, 2008.

[112] A. V. Sirotkin, D. Ovcharenko, R. Grossmann, M. Lauková, and M. Mlynček, "Identification of microRNAs controlling human ovarian cell steroidogenesis via a genome-scale screen," Journal of Cellular Physiology, vol. 219, no. 2, pp. 415-420, 2009.

[113] A. V. Sirotkin, M. Lauková, D. Ovcharenko, P. Brenaut, and M. Mlynček, "Identification of microRNAs controlling human ovarian cell proliferation and apoptosis," Journal of Cellular Physiology, vol. 223, no. 1, pp. 49-56, 2010.

[114] V. Borgdorff, M. E. Lleonart, C. L. Bishop et al., "Multiple microRNAs rescue from Ras-induced senescence by inhibiting $\mathrm{p} 21^{\text {Wafl/Cip1 }}, "$ Oncogene, vol. 29 , no. 15 , pp. 2262-2271, 2010.

[115] M. Izumiya, K. Okamoto, N. Tsuchiya, and H. Nakagama, "Functional screening using a microRNA virus library and microarrays: a new high-throughput assay to identify tumorsuppressive microRNAs," Carcinogenesis, vol. 31, no. 8, pp. 1354-1359, 2010.

[116] A. Serva, B. Knapp, C. Claas et al., "MiR-17 family regulates cargo trafficking," in review.

[117] Y. Sylvestre, V. De Guire, E. Querido et al., "An E2F/miR20a autoregulatory feedback loop," The Journal of Biological Chemistry, vol. 282, no. 4, pp. 2135-2143, 2007.

[118] S. Galardi, N. Mercatelli, E. Giorda et al., "miR-221 and miR-222 expression affects the proliferation potential of human prostate carcinoma cell lines by targeting $\mathrm{p} 27^{\text {Kip } 1}$," The Journal of Biological Chemistry, vol. 282, no. 32, pp. 23716-23724, 2007.

[119] Y. Akao, Y. Nakagawa, and T. Naoe, "let-7 functions as a potential growth suppressor in human colon cancer cells," Biological and Pharmaceutical Bulletin, vol. 29, no. 5, pp. 903906, 2006.

[120] N. Felli, L. Fontana, E. Pelosi et al., "MicroRNAs 221 and 222 inhibit normal erythropoiesis and erythroleukemic cell growth via kit receptor down-modulation," Proceedings of the National Academy of Sciences of the United States of America, vol. 102, no. 50, pp. 18081-18086, 2005.

[121] C. Esau, X. Kang, E. Peralta et al., "MicroRNA-143 regulates adipocyte differentiation," The Journal of Biological Chemistry, vol. 279, no. 50, pp. 52361-52365, 2004.

[122] J. A. Chan, A. M. Krichevsky, and K. S. Kosik, "MicroRNA21 is an antiapoptotic factor in human glioblastoma cells," Cancer Research, vol. 65, no. 14, pp. 6029-6033, 2005. 
[123] J. F. Chen, E. M. Mandel, J. M. Thomson et al., "The role of microRNA-1 and microRNA-133 in skeletal muscle proliferation and differentiation," Nature Genetics, vol. 38, no. 2, pp. 228-233, 2006.

[124] Y. Hayashita, H. Osada, Y. Tatematsu et al., "A polycistronic microRNA cluster, $m i R-17-92$, is overexpressed in human lung cancers and enhances cell proliferation," Cancer Research, vol. 65, no. 21, pp. 9628-9632, 2005.

[125] Y. Lu, J. M. Thomson, H. Y. Wong, S. M. Hammond, and B. L. Hogan, "Transgenic over-expression of the microRNA miR-17-92 cluster promotes proliferation and inhibits differentiation of lung epithelial progenitor cells," Developmental Biology, vol. 310, no. 2, pp. 442-453, 2007.

[126] I. Manni, S. Artuso, S. Careccia et al., "The microRNA miR92 increases proliferation of myeloid cells and by targeting p63 modulates the abundance of its isoforms," FASEB Journal, vol. 23, no. 11, pp. 3957-3966, 2009.

[127] M. T. Pickering, B. M. Stadler, and T. F. Kowalik, "MiR-17 and miR-20a temper an E2F1-induced G1 checkpoint to regulate cell cycle progression," Oncogene, vol. 28, no. 1, pp. 140-145, 2009.

[128] K. A. O’Donnell, E. A. Wentzel, K. I. Zeller, C. V. Dang, and J. T. Mendell, "c-Myc-regulated microRNAs modulate E2F1 expression," Nature, vol. 435, no. 7043, pp. 839-843, 2005.

[129] M. K. Manion and D. M. Hockenbery, "Targeting BCL-2related proteins in cancer therapy," Cancer Biology Therapy, vol. 2, no. 4, pp. S105-S114, 2003.

[130] A. Esquela-Kerscher, P. Trang, J. F. Wiggins et al., "The let-7 microRNA reduces tumor growth in mouse models of lung cancer," Cell Cycle, vol. 7, no. 6, pp. 759-764, 2008.

[131] L. Jiang, Q. Huang, S. Zhang et al., "Hsa-miR-125a-3p and hsa-miR-125a-5p are downregulated in non-small cell lung cancer and have inverse effects on invasion and migration of lung cancer cells," BMC Cancer, vol. 10, article 318, 2010.

[132] G. Meister, M. Landthaler, Y. Dorsett, and T. Tuschl, "Sequence-specific inhibition of microRNA-and siRNAinduced RNA silencing," RNA, vol. 10, no. 3, pp. 544-550, 2004.

[133] R. Pepperkok and J. Ellenberg, "High-throughput fluorescence microscopy for systems biology," Nature Reviews Molecular Cell Biology, vol. 7, no. 9, pp. 690-696, 2006.

[134] R. Sacher, L. Stergiou, and L. Pelkmans, "Lessons from genetics: interpreting complex phenotypes in RNAi screens," Current Opinion in Cell Biology, vol. 20, no. 4, pp. 483-489, 2008.

[135] N. Rajewsky, "MicroRNA target predictions in animals," Nature Genetics, vol. 38, no. 1, supplement, pp. S8-S13, 2006.

[136] M. M. Martin, E. J. Lee, J. A. Buckenberger, T. D. Schmittgen, and T. S. Elton, "MicroRNA-155 regulates human angiotensin II type 1 receptor expression in fibroblast," The Journal of Biological Chemistry, vol. 281, no. 27, pp. 18277-18284, 2006.

[137] P. Brodersen and O. Voinnet, "Revisiting the principles of microRNA target recognition and mode of action," Nature Reviews Molecular Cell Biology, vol. 10, no. 2, pp. 141-148, 2009.

[138] M. Beitzinger, L. Peters, J. Y. Zhu, E. Kremmer, and G. Meister, "Identification of human microRNA targets from isolated argonaute protein complexes," RNA Biology, vol. 4, no. 2, pp. 76-84, 2007.

[139] G. Easow, A. A. Teleman, and S. M. Cohen, "Isolation of microRNA targets by miRNP immunopurification," RNA, vol. 13, no. 8, pp. 1198-1204, 2007.
[140] F. V. Karginov, C. Conaco, Z. Xuan et al., "A biochemical approach to identifying microRNA targets," Proceedings of the National Academy of Sciences of the United States of America, vol. 104, no. 49, pp. 19291-19296, 2007.

[141] A. G. Fraser, R. S. Kamath, P. Zipperlen, M. MartinezCampos, M. Sohrmann, and J. Ahringer, "Functional genomic analysis of C. elegans chromosome I by systematic RNA interference," Nature, vol. 408, no. 6810, pp. 325-330, 2000.

[142] R. S. Kamath, A. G. Fraser, Y. Dong et al., "Systematic functional analysis of the Caenorhabditis elegans genome using RNAi,” Nature, vol. 421, no. 6920, pp. 231-237, 2003.

[143] H. Zhou, M. Xu, Q. Huang et al., "Genome-scale RNAi screen for host factors required for HIV replication," Cell Host and Microbe, vol. 4, no. 5, pp. 495-504, 2008.

[144] A. E. Carpenter and D. M. Sabatini, "Systematic genomewide screens of gene function," Nature Reviews Genetics, vol. 5, no. 1, pp. 11-22, 2004.

[145] C. Falschlehner, S. Steinbrink, G. Erdmann, and M. Boutros, "High-throughput RNAi screening to dissect cellular pathways: a how-to guide," Biotechnology Journal, vol. 5, no. 4, pp. 368-376, 2010.

[146] T. Horn, T. Sandmann, and M. Boutros, "Design and evaluation of genome-wide libraries for RNA interference screens," Genome Biology, vol. 11, no. 6, article R61, 2010.

[147] J. T. Marques and B. R. Williams, "Activation of the mammalian immune system by siRNAs," Nature Biotechnology, vol. 23, no. 11, pp. 1399-1405, 2005.

[148] A. D. Judge, V. Sood, J. R. Shaw, D. Fang, K. McClintock, and I. MacLachlan, "Sequence-dependent stimulation of the mammalian innate immune response by synthetic siRNA," Nature Biotechnology, vol. 23, no. 4, pp. 457-462, 2005.

[149] J. Elmén, H. Thonberg, K. Ljungberg et al., "Locked nucleic acid (LNA) mediated improvements in siRNA stability and functionality," Nucleic Acids Research, vol. 33, no. 1, pp. 439447, 2005.

[150] A. L. Jackson, J. Burchard, J. Schelter et al., "Widespread siRNA "off-target" transcript silencing mediated by seed region sequence complementarity," RNA, vol. 12, no. 7, pp. 1179-1187, 2006.

[151] C. J. Echeverri, P. A. Beachy, B. Baum et al., "Minimizing the risk of reporting false positives in large-scale RNAi screens," Nature Methods, vol. 3, no. 10, pp. 777-779, 2006.

[152] C. J. Echeverri and N. Perrimon, "High-throughput RNAi screening in cultured cells: a user's guide," Nature Reviews Genetics, vol. 7, no. 5, pp. 373-384, 2006.

[153] D. Grimm, K. L. Streetz, C. L. Jopling et al., "Fatality in mice due to oversaturation of cellular microRNA/short hairpin RNA pathways," Nature, vol. 441, no. 7092, pp. 537-541, 2006.

[154] A. L. Jackson and P. S. Linsley, "Recognizing and avoiding siRNA off-target effects for target identification and therapeutic application," Nature Reviews Drug Discovery, vol. 9, no. 1, pp. 57-67, 2010.

[155] F. Stegmeier, G. Hu, R. J. Rickles, G. J. Hannon, and S. J. Elledge, "A lentiviral microRNA-based system for single-copy polymerase II-regulated RNA interference in mammalian cells," Proceedings of the National Academy of Sciences of the United States of America, vol. 102, no. 37, pp. 13212-13217, 2005.

[156] D. Grimm and M. A. Kay, "Therapeutic short hairpin RNA expression in the liver: viral targets and vectors," Gene Therapy, vol. 13, no. 6, pp. 563-575, 2006. 
[157] S. Diederichs, S. Jung, S. M. Rothenberg, G. A. Smolen, B. G. Mlody, and D. A. Haber, "Coexpression of Argonaute2 enhances RNA interference toward perfect match binding sites," Proceedings of the National Academy of Sciences of the United States of America, vol. 105, no. 27, pp. 9284-9289, 2008.

[158] D. P. Bartel and C. Z. Chen, "Micromanagers of gene expression: the potentially widespread influence of metazoan microRNAs," Nature Reviews Genetics, vol. 5, no. 5, pp. 396400, 2004.

[159] E. Del Nery, S. Miserey-Lenkei, T. Falguières et al., "Rab6A and Rab6A' GTPases play non-overlapping roles in membrane trafficking," Traffic, vol. 7, no. 4, pp. 394-407, 2006.

[160] V. Ambros, "MicroRNAs: genetically sensitized worms reveal new secrets," Current Biology, vol. 20, no. 14, pp. R598-R600, 2010.

[161] E. A. Miska, E. Alvarez-Saavedra, A. L. Abbott et al., "Most Caenorhabditis elegans microRNAs are individually not essential for development or viability," PLoS genetics, vol. 3, no. 12, article e215, 2007.

[162] J. L. Brenner, K. L. Jasiewicz, A. F. Fahley, B. J. Kemp, and A. L. Abbott, "Loss of individual microRNAs causes mutant phenotypes in sensitized genetic backgrounds in C. elegans," Current Biology, vol. 20, no. 14, pp. 1321-1325, 2010. 

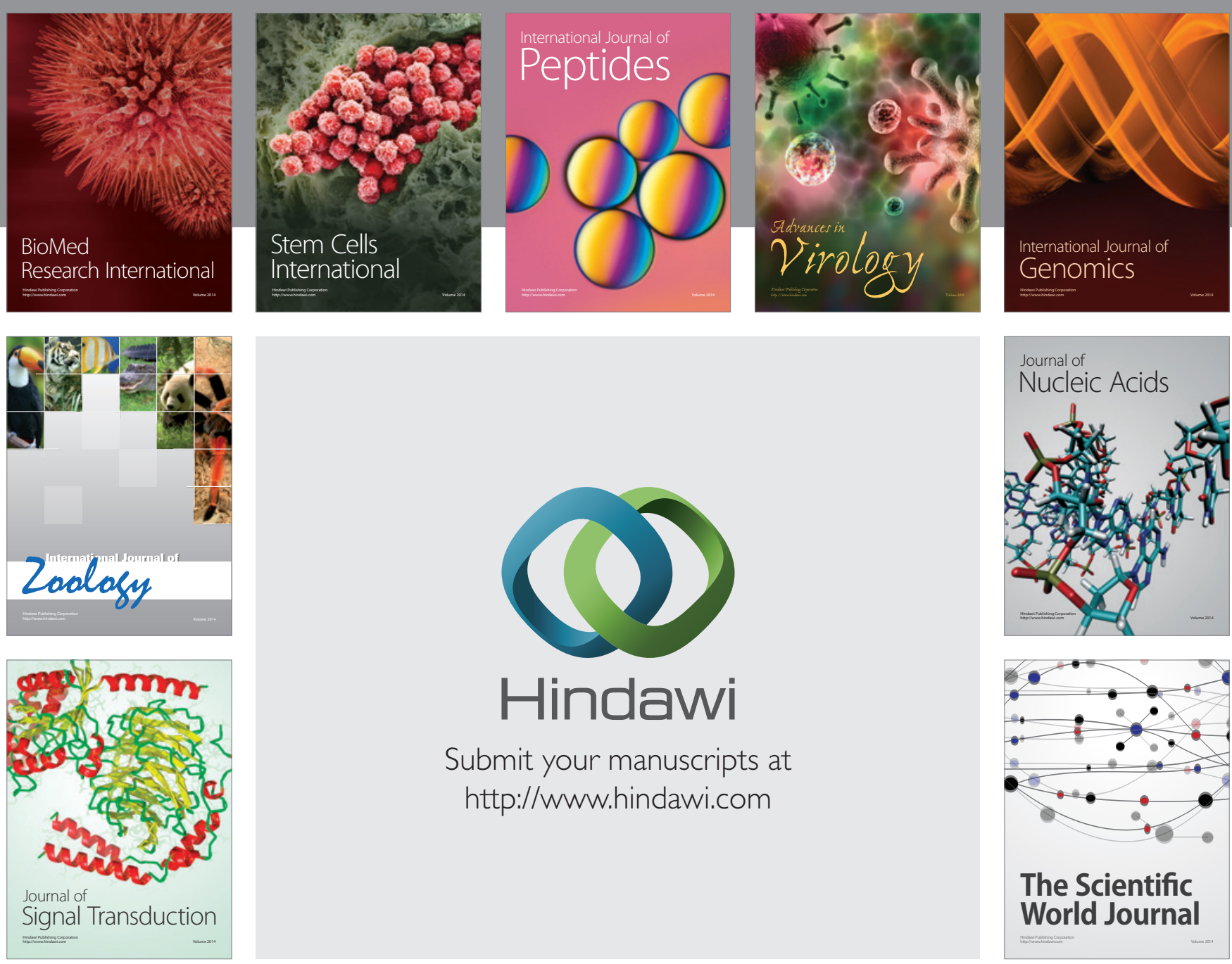

Submit your manuscripts at

http://www.hindawi.com
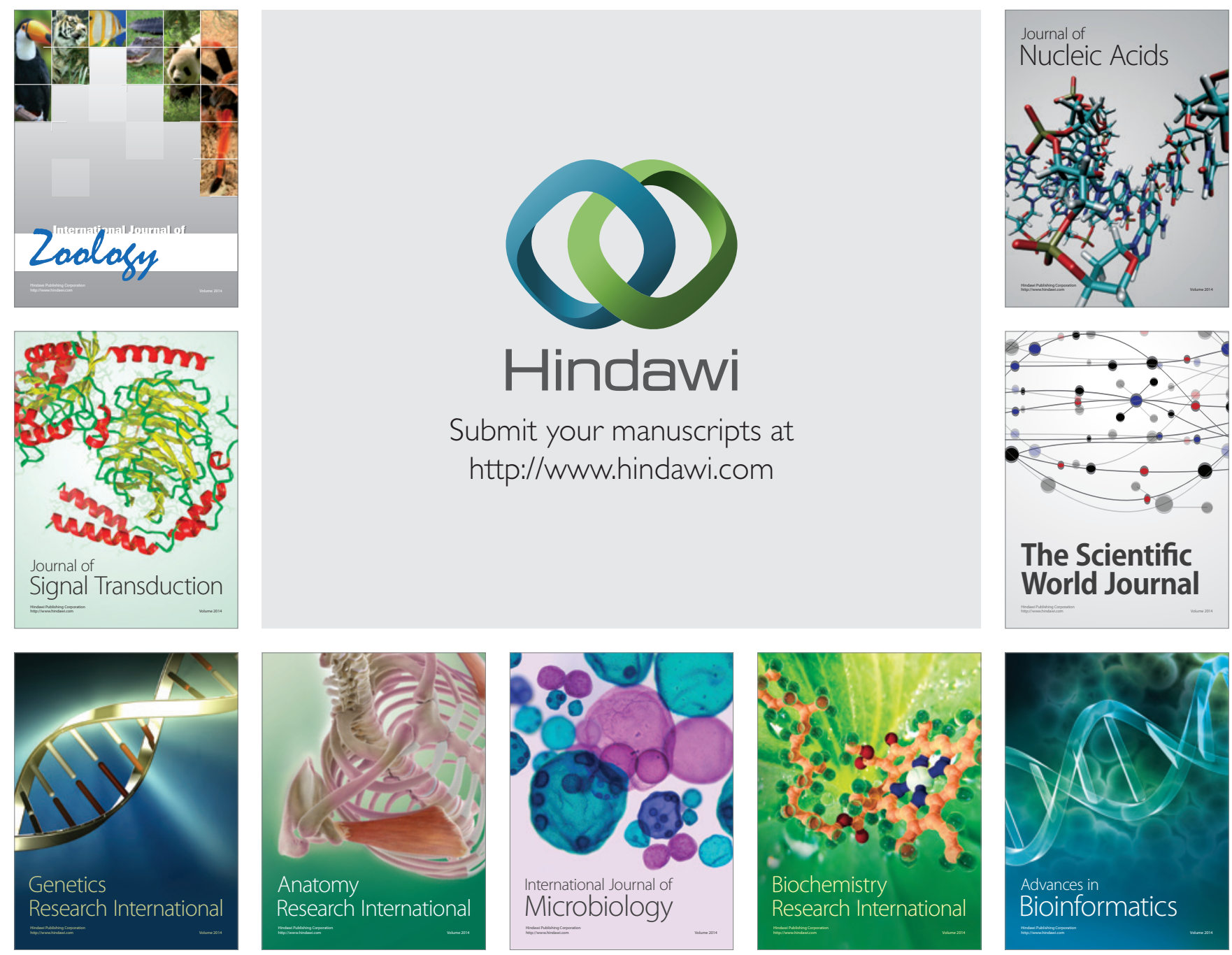

The Scientific World Journal
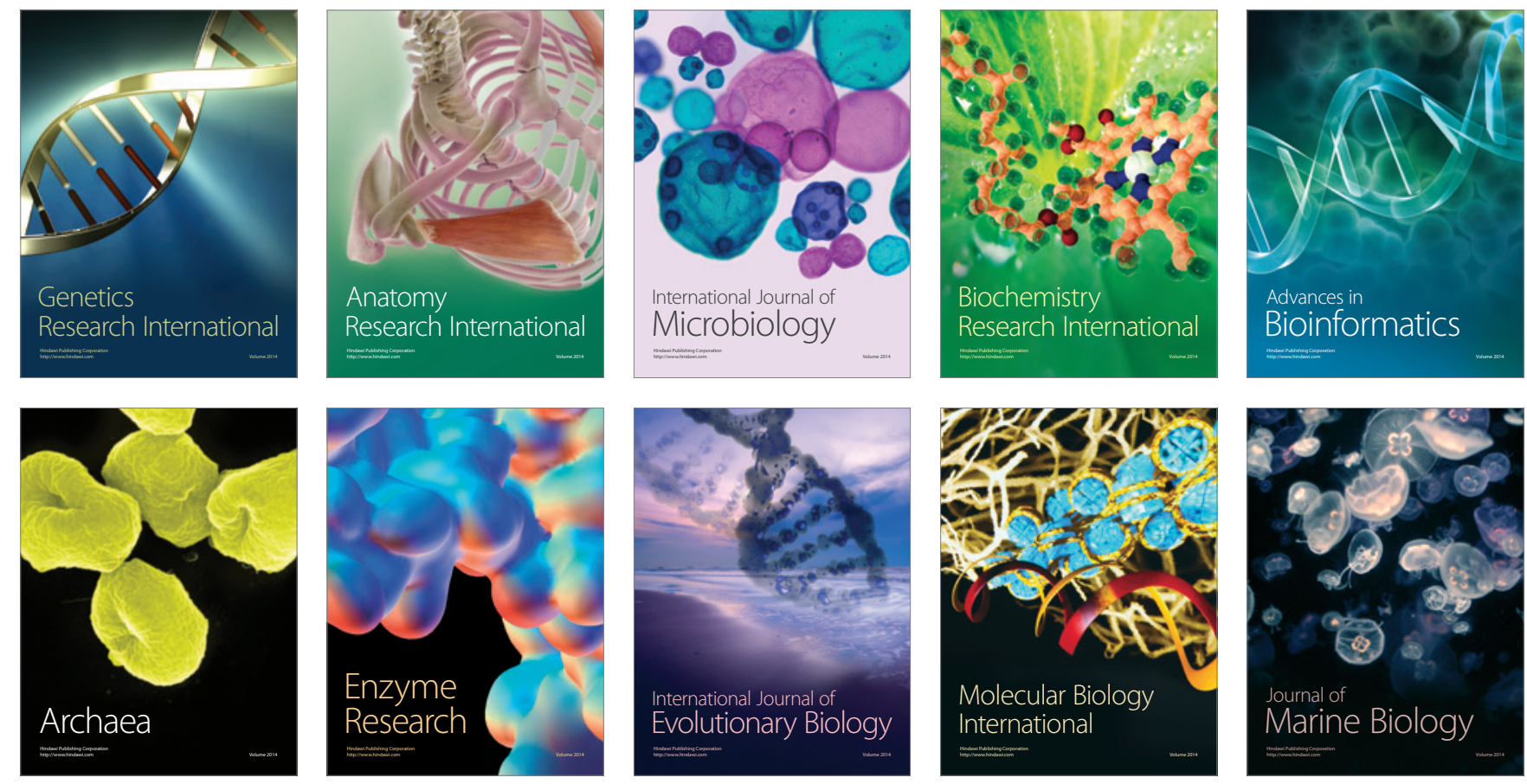